\title{
PROSES PEMURNIAN GAS BUMI SEBAGAI BAHAN BAKU KILANG MINI
}

\section{PURIFICATION PROCESS OF NATURAL GAS AS A MINI PLANT REFINERY FEEDSTOCK}

\author{
(Studi kasus Ladang Marginal Cikarang-Area Operasi Barat EP Pertamina) \\ (Case Study of Cikarang Marginal Field - West EP Pertamina Operation Area) \\ Mohammad Ismail \\ Pusat Teknologi Industri Proses \\ Deputi Teknologi Industri Rancang Bangun \& Rekayasa \\ Badan Pengkajian dan Penerapan Teknologi \\ Gedung Teknologi 2 Lt. 3, Kompleks PUSPIPTEK, Serpong \\ Email : ismailmh_158@yahoo.com
}

\begin{abstract}
Abstrak
Penggunaan gas bumi sebagai bahan bakar otomotif telah cukup banyak digunakan di negara maju. Di Indonesia, penggunaannya telah dikembangkan sejak tahun 1988 meski menghadapi banyak masalah dalam perkembangannya. Ada korelasi antara jarak dari kebutuhan LNG liquefaction plant dengan pengguna akhir. Ada beberapa teknologi yang ekonomis, seperti Mini Plant LNG, terutama dalam penyediaan gas ke daerah-daerah di mana distribusi gas dari kilang besar tidak terjangkau karena kurangnya infrastruktur .Dalam beberapa kasus Mini LNG juga dapat berfungsi untuk cadangan untuk perluasan saluran yang ada, bahkan bisa juga digunakan sebagai cadangan dalam sistem distribusi selama musim puncak. Di sini kita dapat melihat bahwa kilang LNG mini akan ekonomis untuk transportasi dengan jarak sekitar $500 \mathrm{~km}$ dan volume persediaan di bawah 2,5 MMscm/d atau 600-700 Kton/tahun. Mini Plant LNG lebih tepat bagi negaranegara yang memiliki banyak sumber ladang gas marginal yang tersebar di beberapa lokasi geografis dengan kondisi yang lebih kompleks, sehingga untuk sistem jaringan pipa pengembangan investasi terlalu mahal, seperti kondisi pegunungan, rawa, hutan. Dalam hal ini LNG biasanya dikirim menggunakan tangki khusus melalui sungai atau darat. Kapasitas produksi jenis ini berkisar 10500 ton per hari. Kepadatan energi yang tinggi dari LNG juga merupakan salah satu alasan untuk memilih LNG.
\end{abstract}

Kunci kunci : Kilang LNG mini, Gas Bumi, Ladang Gas Marginal

\begin{abstract}
The use of natural gas as an automotive fuel has been quite widely used in developed countries. In Indonesia, its use has been developed since 1988 despite facing many problems in its development. The existence of a correlation between the distance of the needs LNG liquefaction plant to the end user. There are several technologies that are economical, like a mini LNG plant, especially in the supply of gas to the areas where the distribution of gas from large refineries are not due to lack of infrastructure. In some cases LNG mini can also act to reserve for the expansion of existing channels, even can also be used as a backup in the distribution system during peak season. Here we can see that the mini LNG plant is economically more suitable for transport to a distance of about $500 \mathrm{~km}$ and volumes inventory under $2.5 \mathrm{MMscm} / \mathrm{d}$ or 600-700 K tons/year. Mini LNG plant is more appropriate for countries which have many sources of marginal gas fields spread over multiple geographical locations with more complex conditions, so for investment development pipeline network system is too expensive, such as the condition of the mountains, swamps, forests. In this case the LNG usually be sent
\end{abstract}


using a special tank through a river or by land. The production capacity of this type ranged from 10-500 tons per day. High energy density of LNG is also one of the reasons for selecting $L N G$

Keywords : Mini-LNG Plant, Natural Gas, Marginal Gas Fields

Diterima (received) : 12 Maret 2014, Direvisi (reviewed) : 16 Maret 2014,

Disetujui (accepted) : 25 Maret 2014

\section{PENDAHULUAN}

Penggunaan gas bumi sebagai bahan bakar kendaraan bermotor telah cukup banyak digunakan di Negara-negara maju seperti Eropa, Amerika, Jepang dan sejumlah Negara lain seperti Selandia Baru dan Australia.

Di Indonesia penggunaannya sudah mulai dikembangkan sejak tahun 1988 walaupun dalam perkembangannya banyak menghadapi masalah. Salah satu masalah yang utama dalam penggunaan gas bumi untuk bahan bakar kendaraan bermotor adalah ketersediaan dan kontinuitas penyediaan gas bumi yang siap digunakan sebagai bahan bakar. Lokasi ketersediaan yang mudah dicapai merupakan persyaratan mutlak yang harus dipenuhi, untuk itu diperlukan kajian pengadaan serta pengolahan gas bumi menjadi bahan bakar gas (BBG) yang siap digunakan.

Fasilitas utama yang harus dimiliki kilang mini LNG adalah unit $\mathrm{CO}_{2}$ dan $\mathrm{H}_{2} \mathrm{~S}$ removal (tergantung pada spesifikasi gas bumi yang akan dikaji), unit gas dehydration, unit fraksinasi unit water treatment, pengolahan limbah, kompresor dan Genset untuk penyediaan listrik. ${ }^{1)}$

Kajian ini berupa Desain Awal Proses Pemurnian Gas Bumi (unit Gas $\mathrm{CO}_{2}$ dan $\mathrm{H}_{2} \mathrm{~S}$ removal dan unit Gas Dehydration) studi kasus lapangan gas marginal Cikarang-Area Operasi EP Pertamina Jawa Barat yang akan dimanfaatkan sebagai bahan baku Kilang Mini LNG Unit gas $\mathrm{CO}_{2}$ dan $\mathrm{H}_{2} \mathrm{~S}$ removal diperlukan karena keberadaan gas ini selain bersifat korosif juga membahayakan bagi manusia, menimbulkan bau dan mengurangi nilai bakar. Namun alasan yang paling utama adalah karena sifatnya yang korosif sehingga membutuhkan peralatan yang mahal untuk pengolahannya

Unit gas dehydration dimaksudkan untuk mengurangi tingkat kecepatan korosi yang diakibatkan kandungan air dalam gas bumi. Sebelum digunakan di unit gas dehydration, biasanya terlebih dahulu menggunakan inhibitor untuk mengurangi tingkat korosi yang ada. Sedang unit water treatment, dan pengolahan limbah merupakan unit yang umum digunakan dalam industry terutama untuk penyediaan pada proses pengilangan.

\section{BAHAN DAN METODE}

Secara garis besar kajian terhadap perencanaan desain unit gas $\mathrm{CO}_{2}$ dan $\mathrm{H}_{2} \mathrm{~S}$ removal dan unit gas dehydration dilaksanakan dalam beberapa tahap yaitu :

1. Diskripsi proses

2. Perhitungan neraca massa dan panas menggunakan data hasil simulasi

3. Perhitungan dasar peralatan utama

\section{DESKRIPSI PROSES}

Konsep yang ditunjukkan dalam Gambar 1 memperlihatkan adanya korelasi antara kebutuhan LNG terhadap jarak dari kilang pencairan ke pengguna akhir. Ada beberapa teknologi yang ekonomis, seperti kilang LNG mini, terutama dalam penyediaan gas ke daerah-daerah dimana distribusi gas dari kilang besar belum ada karena tidak adanya infrastruktur.

Dalam beberapa hal LNG mini juga dapat bertindak sabagai suatu cadangan untuk perluasan dari saluran yang sudah ada, bahkan dapat juga digunakan sebagai cadangan dalam suatu sistem distribusi selama musim puncak. Disini terlihat bahwa kilang LNG mini secara ekonomis lebih sesuai untuk transportasi dengan jarak sekitar $500 \mathrm{~km}$ dan volume persediaan dibawah 2,5 MMscm/d atau 600-700 K ton/tahun. ${ }^{2)}$

Kilang LNG mini lebih sesuai bagi negara-negara dimana mempunyai banyak sumber ladang gas marginal yang tersebar di beberapa lokasi dengan kondisi geografisnya lebih kompleks, sehingga untuk investasi pembangunan sistem jaringan perpipaan terlalu mahal, seperti kondisi pegunungan, rawa, hutan.

Dalam hal ini LNG biasanya dapat dikirim dengan menggunakan tanki khusus melalui sungai atau darat. Kapasitas produksi dari tipe ini berkisar antara 10-500 ton per hari. Densitas energi yang tinggi dari LNG juga merupakan salah satu alasan untuk memilih LNG secara ekonomi 


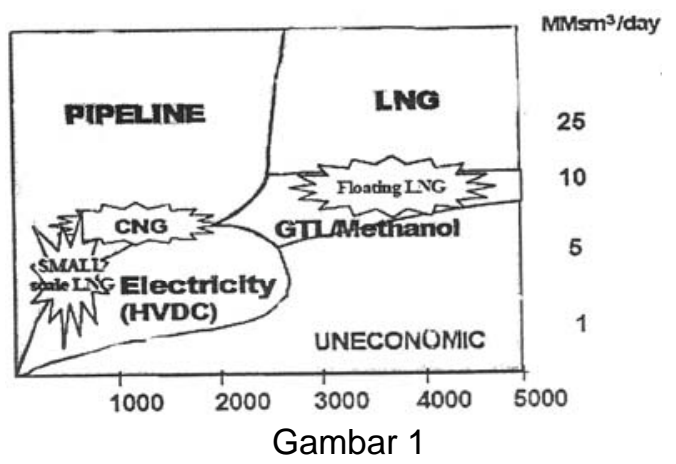

Konsep pemetaan transportasi gas bumi
Ada beberapa lisensi teknologi kilang LNG mini yang banyak digunakan oleh beberapa negara yang mempunyai ladang gas marginal yaitu antara lain : Air Products and Chemicals Inc (USA); Black \& Veatch Pritchard (USA), Chart Industries Inc. (USA); $\mathrm{CH}$-IV Cryogenics (USA); Chicago Bridge \& Iron Company (USA); Chart (USA); Cryogenics (USA); Hamworthy KSE (Norway); KryoPak Inc. (USA) and Linde (Germany). ${ }^{3)}$

Perbandingan berdasarkan kriteria teknis Teknologi Kilang LNG mini yang sudah digunakan dibeberapa negara seperti terlihat di Tabel 1

Tabel 1

Perbandingan teknis Teknologi Kilang LNG mini

\begin{tabular}{|c|c|c|c|}
\hline $\begin{array}{l}\text { KRITERIA } \\
\text { TEKNIS }\end{array}$ & CASCADE & CMR & EXPANDER \\
\hline Effisiensi & Tinggi & Menengah/tinggi & Rendah \\
\hline Kompleksitas & Tinggi & Menengah & Rendah \\
\hline Tipe HE & Plate-fin & Plate-fin/wound coil & Plate-fin \\
\hline $\begin{array}{l}\text { Refrigerant } \\
\text { Storage }\end{array}$ & Ada & Ada & Tidak diperlukan \\
\hline Energy Comp. & $\begin{array}{l}14.1 \mathrm{~kW} / \text { ton- } \\
\text { day LNG }\end{array}$ & $\begin{array}{l}16.81 \mathrm{~kW} / \text { ton- } \\
\text { day LNG }\end{array}$ & $\begin{array}{l}\text { 13-16.5 kW/ton- } \\
\text { day LNG }\end{array}$ \\
\hline Expansion & $\begin{array}{l}\text { Expansion valve } \\
\text { (isenthalpic) }\end{array}$ & $\begin{array}{l}\text { Expansion valve } \\
\text { (isenthalpic) }\end{array}$ & Expander (isentropic) \\
\hline Feed Pressure & Rendah & Tinggi & Rendah \\
\hline Flexibility & Tinggi & Menengah & Tinggi \\
\hline Power Cons & 1.0 & $1.05-1.25$ & $1.7-2.0$ \\
\hline
\end{tabular}

Secara umum desain kilang LNG mini tidak jauh berbeda bila dibandingkan dengan kilang LNG besar. Pemilihan proses mengarah kepada desain yang minimalis. Tipikal kilang LNG mini bisa dilihat pada Gambar 2

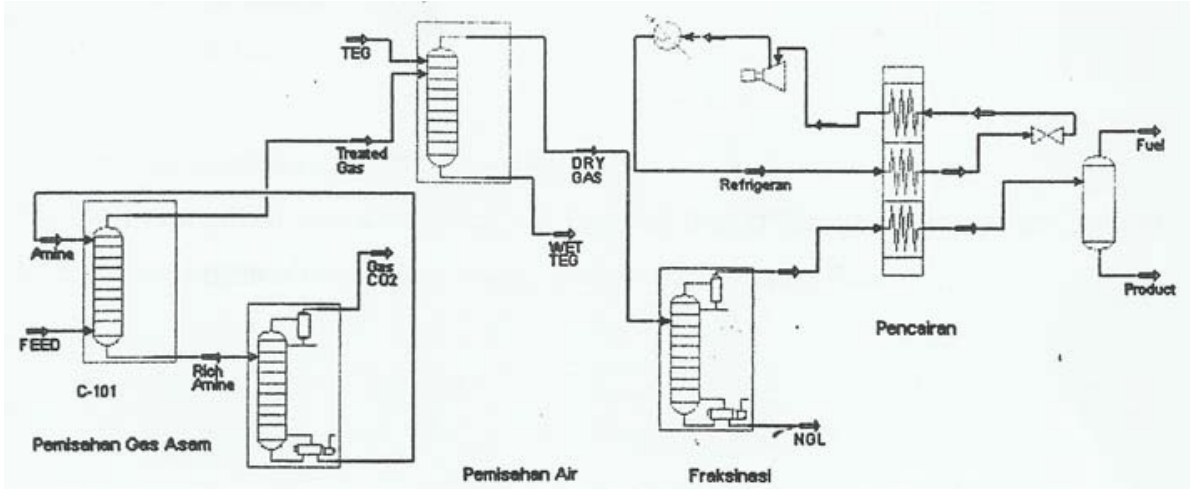

Gambar 2

Tipikal Kilang LNG mini

Pencairan gas bumi pada kilang LNG mini merupakan proses yang didasarkan sebagian besar dilakukan secara fisik dan hanya pada proses pemurnian untuk penghilangan gas asam dilakukan secara kimia. Hal yang perlu dipertimbangkan dalam proses pencairan gas bumi adalah bahan baku yang umumnya

mengandung sejumlah impurities yang harus dihilangkan sebelum masuk pada unit proses pencairan (liquefaction unit), sedangkan kondensat (heavy hydrocarbons) 
dan fraksi LPG dipisahkan dari LNG dilakukan pada unit fraksinasi dengan sistem penurunan temperatur.

Fraksinasi untuk memisahkan hidrokarbon berat biasanya menggunakan rangkaian kolom distilasi (demethaniser, deethaniser, depropaniser dan kadang dilengkapi dengan debutaniser) sehingga proses fraksinasi ini merupakan proses yang banyak mengkonsumsi energi dalam jumlah tinggi (membutuhkan kondensor dan reboiler).

Proses refrigerasi pada pengolahan LNG merupakan proses penurunan temperatur gas bumi hingga temperatur $-160^{\circ} \mathrm{C}$. Proses pencairan diseksi pre-cooling menggunakan campuran refrigeran dengan menggunakan flat-fin exchanger atau spool wound heat exchanger, dan pada seksi pencairan sistem yang digunakan iso-entropic expander LNG plant berdasarkan pada pencairan menggunakan refrigerant dengan faktor utama : ${ }^{4)}$

a. Perbedaan temperatur antara fluida panas dan fluida dingin (refrigeran)

b. Pencairan secara iso-entropic expander

c. Efisiensi kompresor refrigeran

Berdasarkan kondisi gas bumi dan spesifikasi produk LNG, proses pencairan gas bumi pada kilang LNG terdiri dari :

a. Pemisahan gas karbondioksida

b. Pemisahan air

c. Pemisahan hidrikarbon berat

d. Pencairan gas bumi

\section{Proses Pemisahan Gas Karbondioksida}

Proses pemisahan gas asam bertujuan untuk menghilangkan gas asam sesuai dengan spesifikasi pemisahan seperti yang terlihat pada Tabel $2^{1)}$

Tabel 2

Spesifikasi Pemisahan Gas Asam

\begin{tabular}{ccl}
\hline Item & Spesifikas & \multicolumn{1}{c}{ Keterangan } \\
\hline CO2 & $50 \mathrm{ppm}$ & Kelarutan \\
H2S & $3.5 \mathrm{ppm}$ & Spesifikasi LNG \\
Total & $30 \mathrm{mg} / \mathrm{NM}^{3}$ & Spesifikasi LNG \\
Sulfur & & \\
\hline
\end{tabular}

Proses pemisahan gas karbondioksida diawali dengan pengkondisian umpan gas bumi sesuai dengan kondisi operasi absorber. Gas bumi dan larutan lean amine beroperasi secara counter current di absorber. Target operasi absorber adalah fraksi berat karbondioksida pada gas keluaran absorber dibawah 50 ppm.

Larutan rich amine selanjutnya dialirkan ke kolom distilasi atau regenerator untuk melepaskan gas karbondioksida. Spesifikasi operasional kolom regenerator adalah fraksi korbondioksida pada bootom product, dan kemurnian $\mathrm{CO}_{2}$ adalah 92,6\% dengan kandungan air 6,7\%. Untuk mengurangi beban utilitas larutan amina keluaran regenerator didinginkan (pertukaran panas) dengan larutan rich amina dalam heat exchanger.

\section{Proses Penghilangan Air}

Proses ini bertujuan untuk menghilangkan air (jika gas bumi yang digunakan sebagai bahan baku dari jenis wet gas). Gas bumi dan larutan dry TEG beroperasi secara counter current di absorber. Target operasional absorber adalah farksi berat air pada gas keluaran absorber seminimal mungkin.

Larutan wet TEG selanjutnya dialirkan ke kolom distilasi atau regenerator untuk melepaskan air. Spesifikasi operasional kolom regenerator adalah fraksi air pada bottom product. Untuk mengurangi beban utilitas larutan TEG keluaran regenerator didinginkan (pertukaran panas) dengan larutan wet TEG dalam heat exchanger.

\section{Proses Pemisahan Hidrokarbon Berat.}

Proses pemisahan hidrokarbon berat bertujuan untuk memisahkan etana dari hidrokarbon yang lebih berat untuk memenuhi spesifikasi produk. Pemisahan diawali dengan pengkondisian aliran gas melalui pendinginan dengan propana. Pada skala besar alat penukar panas ini sering disebut propane pre-cooler. Proses fraksinasi dilakukan dalam kolom distilasi dengan produk atas adalah gas proses dan produk bawah natural gas liquid (NGL). NGL ini difraksinasi lebih lanjut sesuai kebutuhan (etana cair, LPG, Bahan bakar).

Kolom fraksinasi merupakan kolom distilasi (try column). Spesifikasi kolom adalah fraksi molar gas metana pada produk atas.

\section{Proses Pencairan dan Siklus Refrigeran}

Proses pencairan gas merupakan proses inti pada kilang LNG. Gas dikondensasi kemudian di subcooling dalam Main Heat Exchanger (MHE) dengan menggunakan refrigeran (metana, propana, butana dan pentana yang diambil dari fraksinasi). Kemudian tekanan LNG diturunkan sampai tekanan penyimpanan.

Refrigeran mengalami siklus yang diawali dengan mendinginkan refrigeran di MHE kemudian diekspansi sehingga menjadi refrigeran cair. Refrigeran cair berfungsi sebagai madia pendingin di MHE. Refrigeran 
yang keluar dari MHE kemudian dikompresi dan didinginkan kembali ke temperatur normal
Perbandingan kapasitas kilang mini dengan harga dan beban kompresor bisa dilihat pada Gambar 3

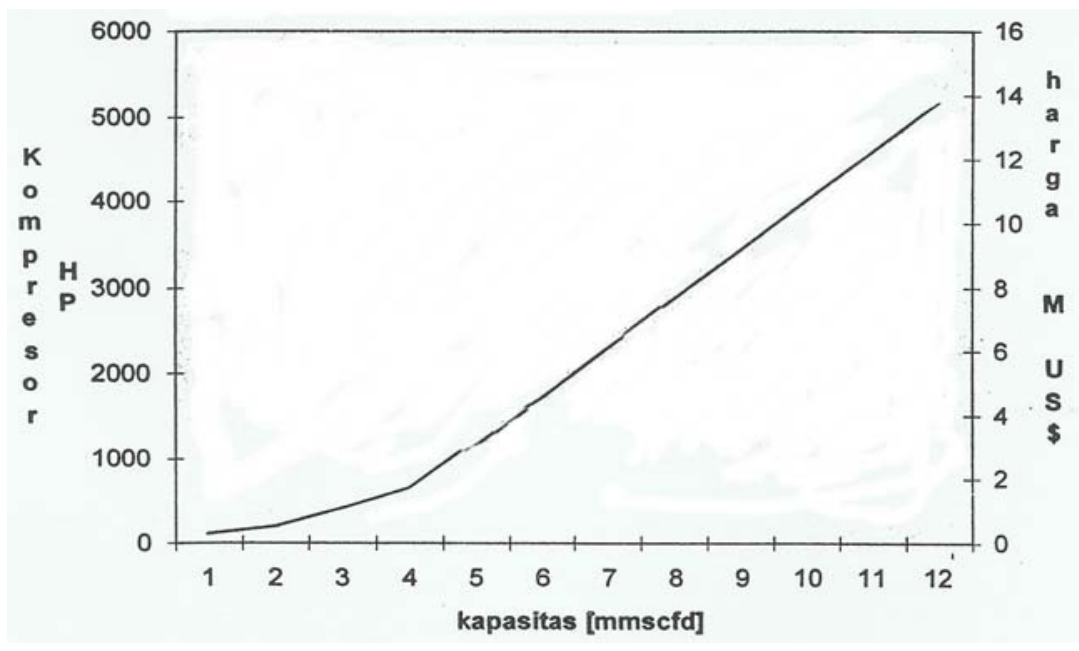

Gambar 3

Kapasitas, Beban Kompresor Dan Harga Kilang LNG Mini

\section{PEMBAHASAN DAN HASIL}

\section{Spesifikasi Bahan Baku dan Produk LNG}

Spesifikasi bahan baku gas bumi dari ladang gas marginal Cikarang-area operasi barat EP Pertamina dapat dilihat pada Tabel 3

Tabel 3

Spesifikasi Gas Bumi

\begin{tabular}{llc}
\hline Parameter & Satuan & Nilai \\
\hline Laju alir & $\mathrm{K}$ mol/h & 266,8 \\
Temperatur & ${ }^{\circ} \mathrm{C}$ & 30 \\
Tekanan & Bar & 53,94 \\
Komposisi & $\%$ & \\
Nitrogen & & 0,24 \\
Karbondioksida & 0,16 \\
Metana & 99,18 \\
Etana & 0,19 \\
Propana & 0,12 \\
i-butana & 0,06 \\
n-butana & 0,04 \\
i-pentana & 0,01 \\
n-pentana & 0,00 \\
n-hexana & 0,00 \\
$\mathrm{H}_{2} \mathrm{~S}$ & 0,00 \\
$\mathrm{H}_{2} \mathrm{O}$ & 0,00 \\
\hline
\end{tabular}

Spesifikasi gas bumi hasil pemurnian dari unit gas $\mathrm{CO}_{2}$ dan $\mathrm{H}_{2} \mathrm{~S}$ removal dan unit gas dehydration sebagai bahan baku kilang LNG mini seperti pada Tabel 4
Tabel 4

Spesifikasi Gas Bumi Hasil Peurnian

\begin{tabular}{lcc} 
Parameter & Satuan & Nilai \\
\hline Temperatur & ${ }^{\circ} \mathrm{C}$ & 114,6 \\
Tekanan & Bar & 53 \\
Komposisi & $\%$ & \\
Nitrogen & & 0,24 \\
Karbondioksida & 0,00 \\
Metana & 99,32 \\
Etana & 0,19 \\
Propana & 0,12 \\
i-butana & 0,06 \\
n-butana & 0,04 \\
i-pentana & 0,01 \\
n-pentana & 0,00 \\
n-hexana & 0,00 \\
$\mathrm{H}_{2} \mathrm{~S}$ & 0,00 \\
$\mathrm{H}_{2} \mathrm{O}$ & 0,01 \\
\hline
\end{tabular}


Hasil perhitungan Neraca Massa dan Energi $\mathrm{CO}_{2}$ removal dengan menggunakan software seperti terlihat di Tabel 5 dan Neraca Massa dan Energi TEG dehydrasi seperti terlihat di Tabel 6

Tabel 5

Neraca Massa dan Energi $\mathrm{CO}_{2}$ Removal

\begin{tabular}{|c|c|c|c|c|c|c|c|c|c|}
\hline & & NG Feed & $\begin{array}{l}\text { DEA to } \\
\text { Contactor }\end{array}$ & $\begin{array}{c}\text { NG to } \\
\text { Dehydration } \\
\text { Plant }\end{array}$ & Rich DEA & $\begin{array}{c}\text { DEA to Flash } \\
\text { TK }\end{array}$ & Flash Vap & Rich to L/R & Regen Feed \\
\hline Vapour Fraction & & 1 & 0 & 0.999886854 & 0 & 8.99E-04 & 1 & 0 & 5.98E-05 \\
\hline Temp & ${ }^{\circ} \mathrm{C}$ & 30 & 40 & 40.09 & 39.03 & 39.02 & 39.02 & 39.02 & 95 \\
\hline Pressure & $\mathrm{kPa}$ & 5394 & 5359 & 5344 & 5394 & 550 & 550 & 550 & 480 \\
\hline Molar Flow & Kgmol/h & 266.8 & 1088.53 & 265.77 & 1089.56 & 1089.56 & 10.98 & 1088.58 & 1088.58 \\
\hline Mass Flow & $\mathrm{Kg} / \mathrm{h}$ & 4328.665 & 25574.336 & 4301.275 & 25601.727 & 25601.727 & 15.796 & 25585.931 & 25585.93 \\
\hline Std Liquid Vol Flow & $\mathrm{M}^{3} / \mathrm{h}$ & 14.33 & 25 & 14.25 & 25.07 & 25.07 & 0.05 & 25.02 & 25.02 \\
\hline Heat Flow & $\mathrm{kJ} / \mathrm{h}$ & 3434233.35 & -29700080.68 & 3523149.30 & -29792810.29 & -29792810.29 & 12882.27 & -29805692.5 & 24247818.6 \\
\hline Molar Enthalpy & $\mathrm{kJ} / \mathrm{gmol}$ & 12871.94 & -27284.56 & 13256.53 & -27343.80 & -27343.80 & 13154.85 & -27380.24 & -22274.64 \\
\hline
\end{tabular}

Tabel Neraca Massa dan Energi $\mathrm{CO}_{2}$ Removal (lanjutan)

\begin{tabular}{|c|c|c|c|c|c|c|c|c|}
\hline & & DEA to Cool & DEA to Pump & $\begin{array}{l}\text { DEA to } \\
\text { Recycle }\end{array}$ & Cond Q & $\begin{array}{c}\text { DEA to } \\
\text { Cool }\end{array}$ & $\begin{array}{c}\text { DEA to } \\
\text { Pump }\end{array}$ & $\begin{array}{l}\text { DEA to } \\
\text { Recycle }\end{array}$ \\
\hline Vapour Fraction & & 0 & 0 & 0 & <empty> & $<e m p t y>$ & $<e m p t y>$ & $<e m p t y>$ \\
\hline Temp & ${ }^{\circ} \mathrm{C}$ & 70.79 & 38.18 & 40 & $<$ empty > & $<e m p t y>$ & $<e m p t y>$ & $<e m p t y>$ \\
\hline Pressure & $\mathrm{kPa}$ & 150 & 115 & 5359 & <empty> & $<e m p t y>$ & $<e m p t y>$ & $<e m p t y>$ \\
\hline Molar Flow & Kgmol/h & 1088.54 & 1088.54 & 1088.54 & <empty> & $<e m p t y>$ & $<e m p t y>$ & $<e m p t y>$ \\
\hline Mass Flow & $\mathrm{Kg} / \mathrm{h}$ & 25574.36 & 25574.36 & 25574.36 & <empty> & $<e m p t y>$ & $<e m p t y>$ & $<e m p t y>$ \\
\hline Std Liquid Vol Flow & $\mathrm{M}^{3} / \mathrm{h}$ & 25 & 25 & 25 & <empty> & $<e m p t y>$ & $<e m p t y>$ & $<e m p t y>$ \\
\hline Heat Flow & $\mathrm{kJ} / \mathrm{h}$ & -26688364.74 & -29874350.10 & -29700144.63 & 27016.76 & 3168488.61 & 3185985.35 & 174205.47 \\
\hline Molar Enthalpy & $\mathrm{kJ} / \mathrm{gmol}$ & -24517.69 & -27444.54 & -27284.51 & <empty> & $<e m p t y>$ & $<e m p t y>$ & $<e m p t y>$ \\
\hline
\end{tabular}


Tabel 6

Neraca Massa dan Energi TEG Dehydration

\begin{tabular}{|c|c|c|c|c|c|c|c|c|c|}
\hline & & TEG Feed & $\begin{array}{l}\text { NG from CO2 } \\
\text { Removal Plant }\end{array}$ & $\begin{array}{l}\text { Gas to } \\
\text { Contactor }\end{array}$ & FWKO & Dry Gas & Rich TEG & LP TEG & $\begin{array}{c}\text { Regen } \\
\text { Btms }\end{array}$ \\
\hline Vapour Fraction & & 0 & 0 & 1 & 0 & $1.00 \mathrm{E}+00$ & 0 & 1.80E-02 & 0 \\
\hline Temp & ${ }^{\circ} \mathrm{C}$ & 50 & 40.1 & 40.1 & 40.1 & 42.2 & 41.5 & 46.3 & 205.0 \\
\hline Pressure & $\mathrm{kPa}$ & 5344 & 5344 & 5344 & 5344 & 5334 & 5344 & 215 & 138 \\
\hline Molar Flow & Kgmol/h & 2.470 & 265.8000 & 265.770 & 0.030 & 265.312 & 2.928 & 2.928 & 2.470 \\
\hline Mass Flow & $\mathrm{Kg} / \mathrm{h}$ & 337.947 & 4301.797 & 4301.252 & 0.544 & 4293.099 & 346.100 & 346.100 & 337.908 \\
\hline \multirow{2}{*}{$\begin{array}{l}\text { Std Liquid Vol Flow } \\
\text { Heat Flow }\end{array}$} & $\mathrm{M}^{3} / \mathrm{h}$ & 0.3 & 14.255 & 14.254 & 0.001 & 14.244 & 0.310 & 0.310 & 0.300 \\
\hline & $\mathrm{kJ} / \mathrm{h}$ & -1825482.8 & -20065654.6 & -20057069.8 & -8584.8 & 19931696.3 & $1951009.7^{-}$ & $1951009.7^{-}$ & 1688849.26 \\
\hline Molar Enthalpy & $\mathrm{kJ} / \mathrm{gmol}$ & & & & & & & & \\
\hline
\end{tabular}

Tabel Neraca Massa dan Energi TEG Dehydration (lanjutan)

\begin{tabular}{|c|c|c|c|c|c|c|c|c|c|}
\hline & & Lean from $L / R$ & Regen Feed & Sour Gas & MakeUp TEG & TEG to Pump & Pump Out & $\begin{array}{c}\text { TEG to } \\
\text { Recycle }\end{array}$ & Sales Gas \\
\hline Vapour Fraction & & 0 & 0 & $1.80 \mathrm{E}-02$ & 0 & 0 & 0 & 0 & 0 \\
\hline Temp & ${ }^{\circ} \mathrm{C}$ & 149.3 & 110.0 & 107.0 & 30.0 & 149.3 & 148.5 & 50.00 & 49.56 \\
\hline Pressure & $\mathrm{kPa}$ & 68 & 145 & 136 & 68 & 68 & 5414 & 5344 & 5299 \\
\hline Molar Flow & $\mathrm{Kgmol} / \mathrm{h}$ & 2.470 & 2.928 & 0.458 & 0.000 & 2.470 & 2.470 & 2.470 & 265.312 \\
\hline Mass Flow & $\mathrm{Kg} / \mathrm{h}$ & 337.908 & 346.100 & 8.193 & 0.039 & 337.947 & 337.947 & 337.947 & 4293.099 \\
\hline Std Liquid Vol Flow & $\mathrm{M}^{3} / \mathrm{h}$ & 0.300 & 0.310 & 0.010 & 0.000 & 0.300 & 0.300 & 0.300 & 14.244 \\
\hline Heat Flow & $\mathrm{kJ} / \mathrm{h}$ & -1744216.85 & -1895642.16 & -100047.31 & -212.26 & -1744429.11 & -1742052.05 & -1825487.50 & -19848260.85 \\
\hline Molar Enthalpy & $\mathrm{kJ} / \mathrm{gmol}$ & & & & & & & & \\
\hline
\end{tabular}


Tabel Neraca Massa dan Energi TEG Dehydration (lanjutan)

\begin{tabular}{lcrrrr} 
& & TEG Only & $\begin{array}{c}\text { Water } \\
\text { Dewpoint }\end{array}$ & $\begin{array}{c}\text { NG to Refrigated } \\
\text { Gas Plant }\end{array}$ & XS $\mathrm{H}_{2} \mathbf{O}$ \\
\hline Vapour Fraction & & 0 & 0.999998193 & 1 & 0 \\
Temp & ${ }^{\circ} \mathrm{C}$ & 25.00 & -0.01 & -0.01 & -0.01 \\
Pressure & $\mathrm{KPa}$ & 5300 & 5300 & 5300 & 5300 \\
Molar Flow & $\mathrm{Kgmol} / \mathrm{h}$ & 0.000 & 265.312 & 265.311 & 0.000 \\
Mass Flow & $\mathrm{Kg} / \mathrm{h}$ & 0.018 & 4293.081 & 4293.072 & 0.009 \\
Std Liquid Vol Flow & $\mathrm{M} / \mathrm{h}$ & 0.000 & 14.244 & 14.244 & 0.000 \\
Heat Flow & $\mathrm{kJ} / \mathrm{h}$ & -96.66 & -20406791.92 & -20406654.17 & -137.76 \\
Molar Enthalpy & $\mathrm{kJ} / \mathrm{gmol}$ & & & & \\
\hline
\end{tabular}

Diagram alir desain $\mathrm{CO}_{2}$ removal seperti terlihat di Gambar 3

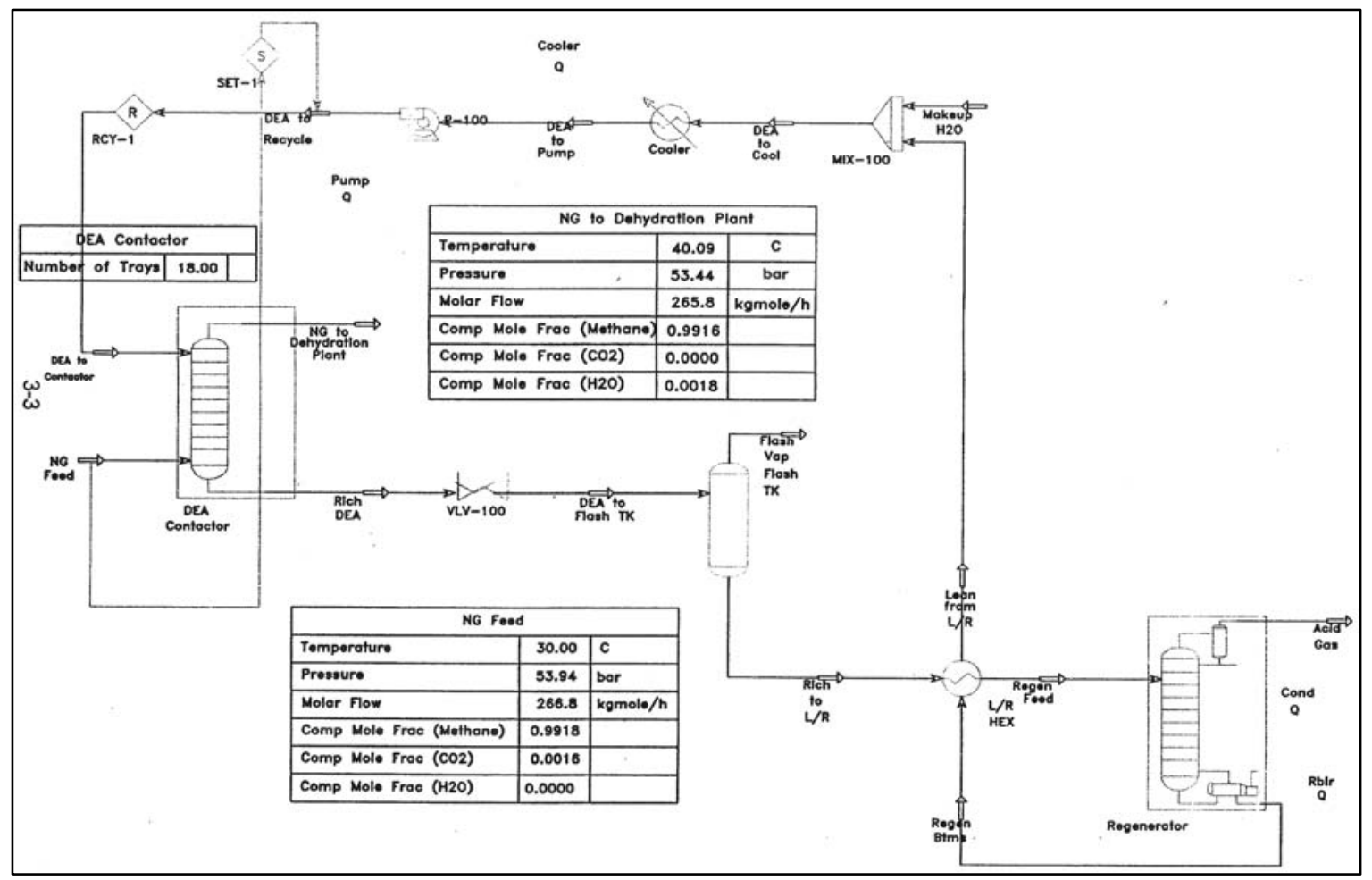

Gambar 3

Flow Diagram $\mathrm{CO}_{2}$ Removal 
Diagram alir desain TEG dehydrasi seperti terlihat di Gambar 4

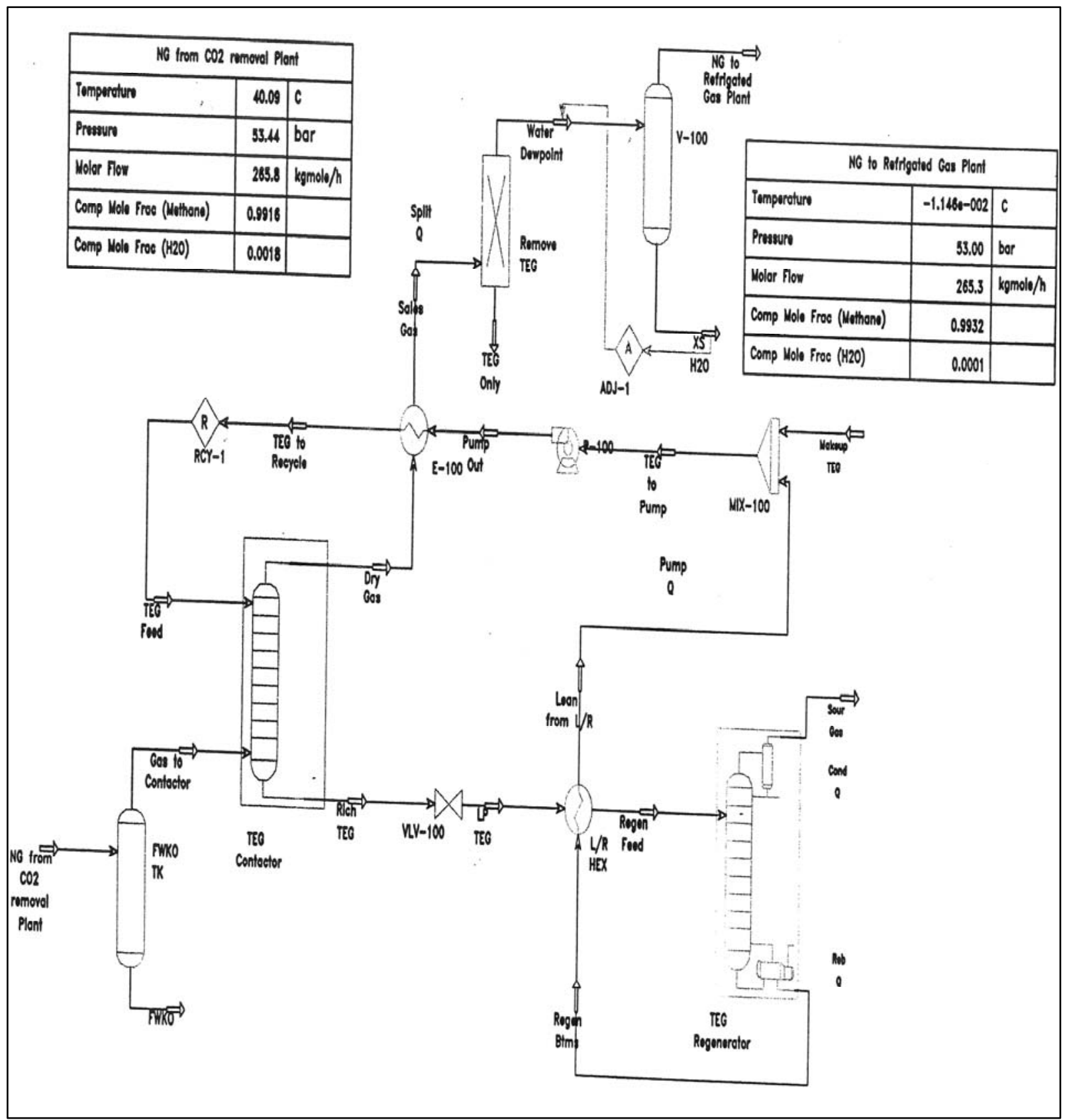

Gambar 4

Flow Diagram Desain TEG Dehydration 


\section{PERHITUNGAN PERALATAN UTAMA}

Sebagian Desain peralatan utama LNG Mini Plant Heat Exchanger dan Tube Layout hasil Programing seperti terlihat di Gambar 5 s/d 8

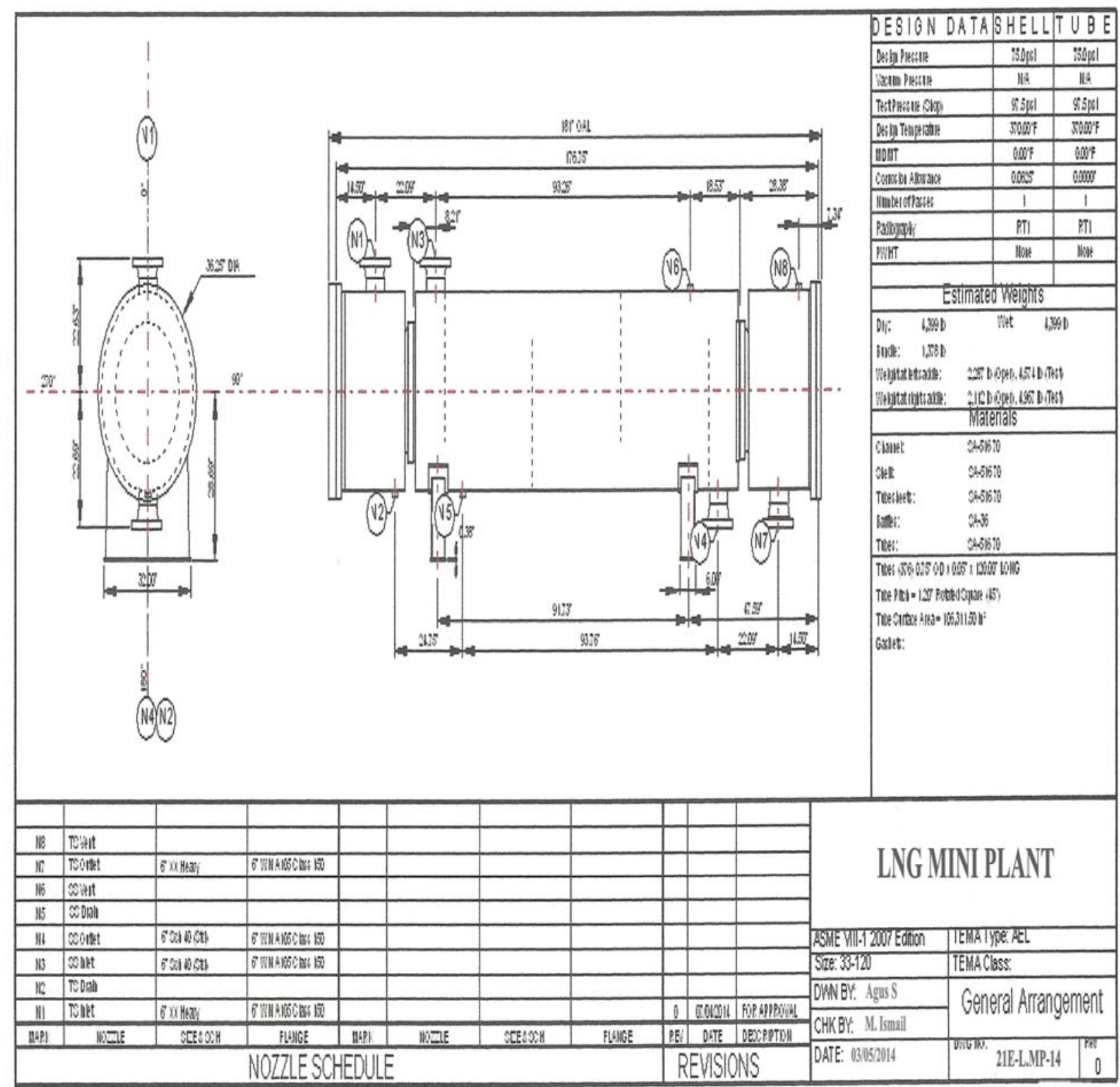

Gambar 5

Desain Peralatan $\mathrm{CO}_{2}$ Regenerator Reboiler 


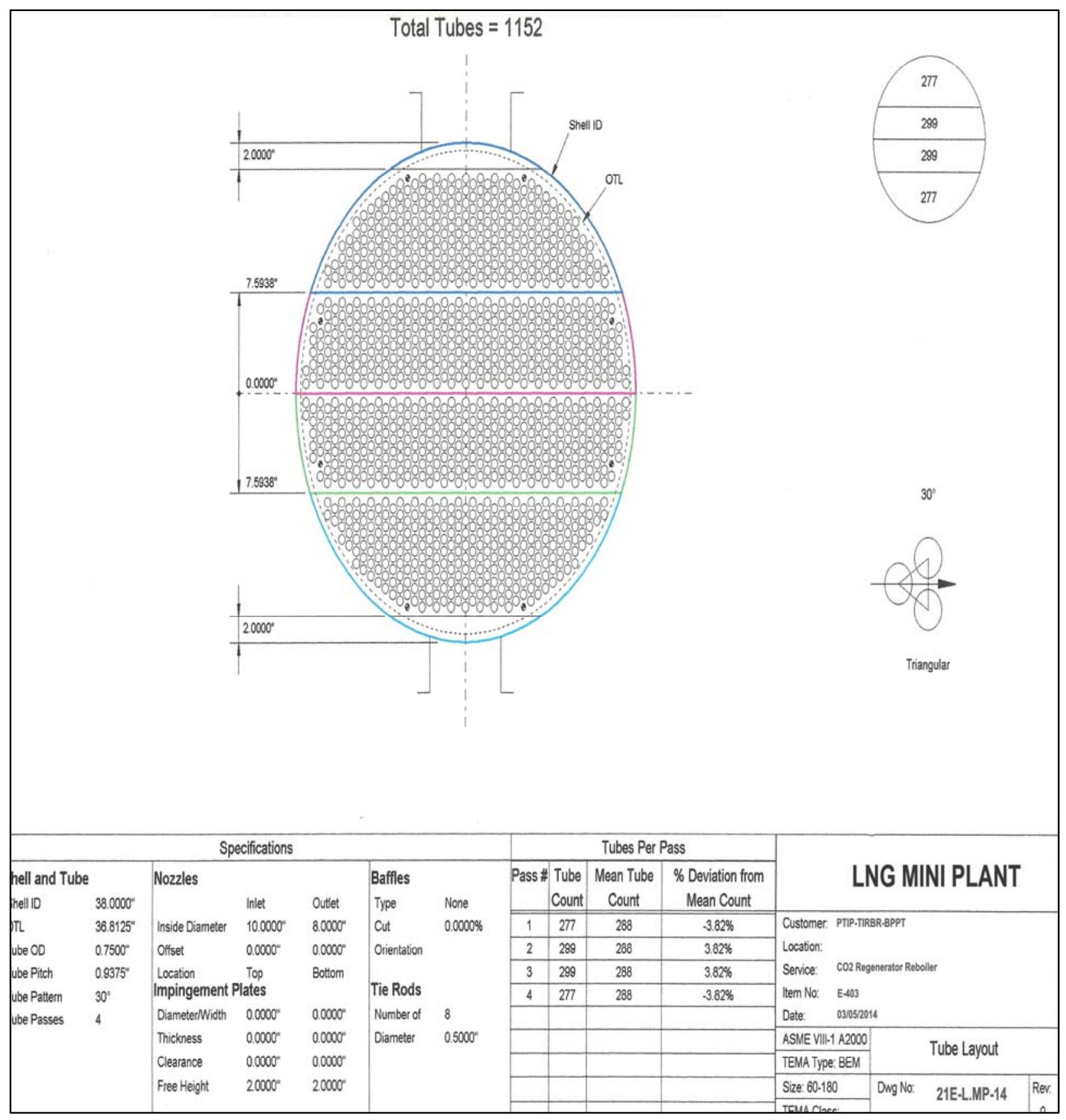

Gambar 6

Desain Peralatan Tube Layout $\mathrm{CO}_{2}$ Regenerator Reboiler 


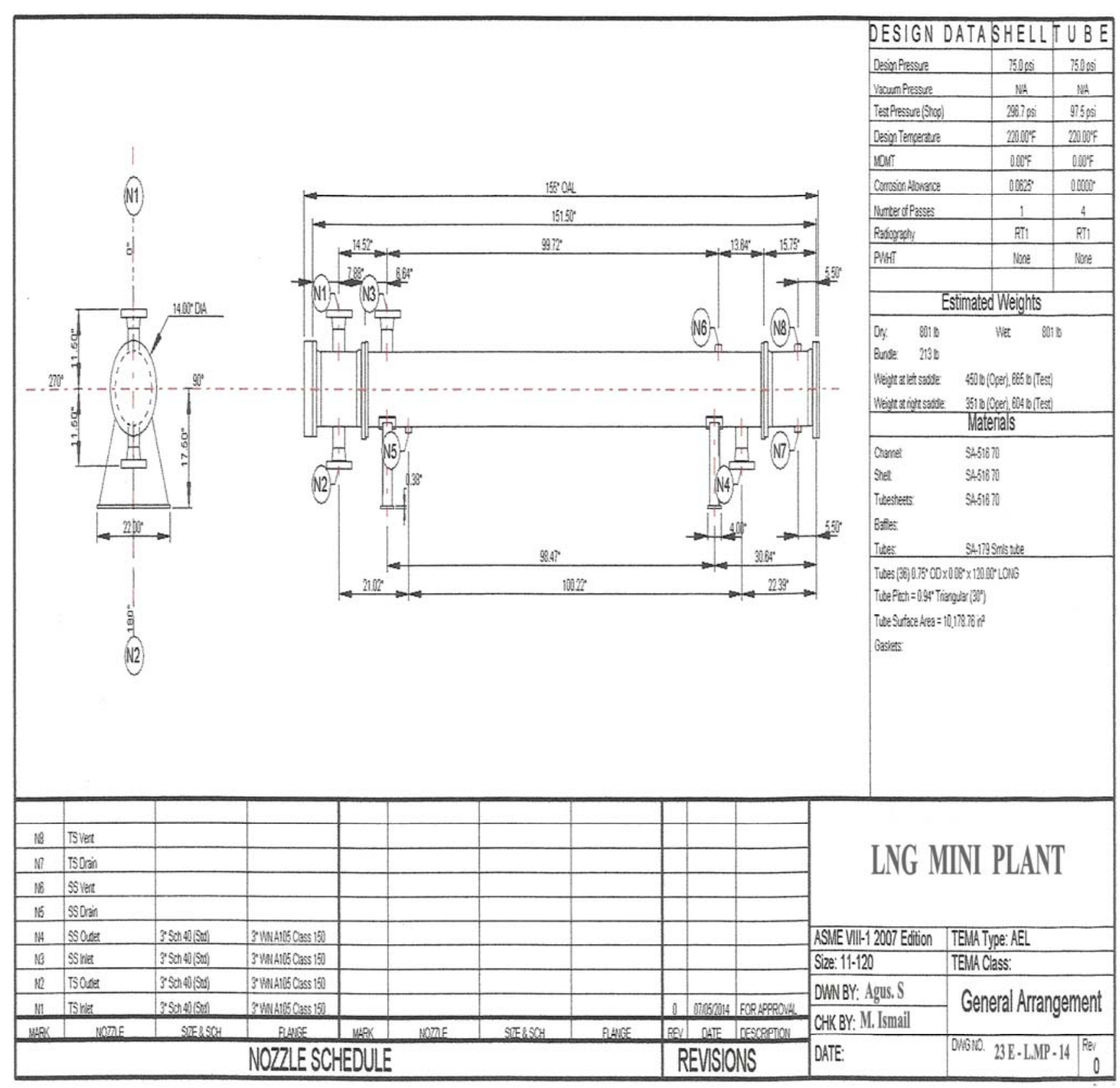

Gambar 7

Desain Peralatan $\mathrm{CO}_{2}$ Cooler (Heat Exchanger) 


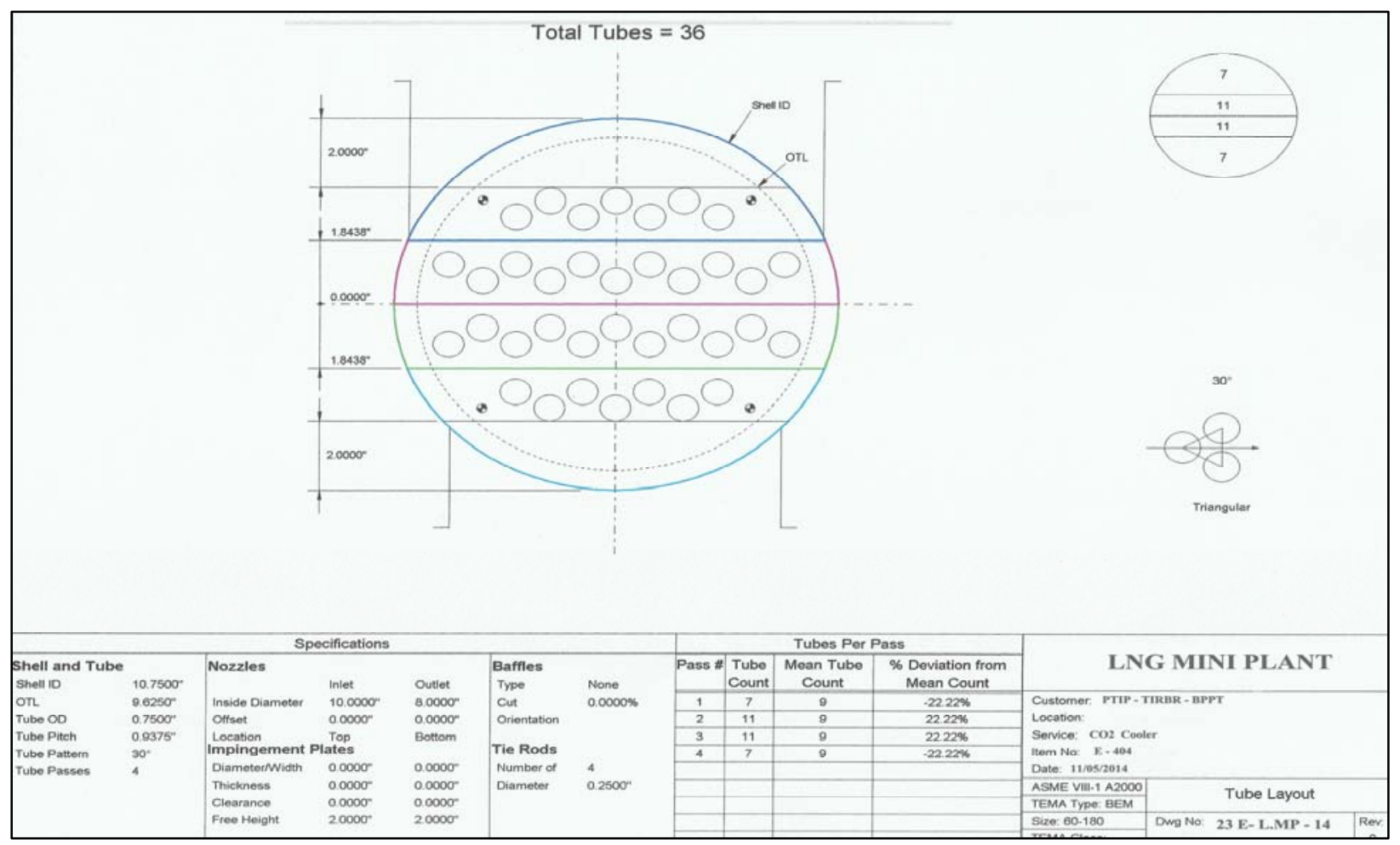

Gambar 8

Desain Peralatan Tube Layout $\mathrm{CO}_{2}$ Cooler (Heat Exchanger)

\section{PEMBAHASAN}

Pemanfaatan ladang gas bumi marginal merupakan salah satu solusi untuk mengatasi krisis energi di Indonesia,untuk itu perlu adanya dukungan dalam merealisasikan produksi gas bumi untuk mengoptimalkan pemanfaat ladang gas marginal,salah satunya mendirikan kilang mini LNG. Tahapan pendirian kilang mini LNG yaitu penelitian terhadap kandungan gas pada ladang marginal, infrastruktur, pasar dan teknologi yang tepat untuk memproduksi gas bumi tersebut.

Penelitian yang dilakukan yaitu berupa pembuatan Desain Awal Proses Pemurnian Gas Bumi, studi kasus lapangan gas marginal Cikarang-Area Operasi EP Pertamina Jawa Barat yang akan dimanfaatkan sebagai bahan baku Kilang mini LNG beserta analisa tekno ekonomi.

\section{Bahan Baku}

Spesifikasi bahan baku gas bumi dari ladang gas marginal Cikarang-area operasi wilayah barat EP Pertamina yaitu metana $99,18 \%$, etana $0.19 \%$,propana $0.12 \%$ dan fraksi berat $0.11 \%$, sedangkan impuritisnya yaitu nitrogen $0.24 \%, \mathrm{CO}_{2}=0.16 \%, \mathrm{H}_{2} \mathrm{~S}=$ $0.00 \%$ dan air.

Dilihat dari spesifikasi bahan baku menunjukkan bahwa untuk pemurnian bahan baku hanya menggunakan proses $\mathrm{CO}_{2}$ removal dan dehydration, sedangkan untuk proses penghilangan $\mathrm{H}_{2} \mathrm{~S}$ tidak perlu dilakukan, karena kandungannya sangat kecil dan masih dibawah ambang batas persyaratan untuk produk LNG.

Hasil dari pemurnian diharapkan kandungan metana pada gas bumi meningkat menjadi $99.32 \%$ dan kandungan $\mathrm{H}_{2} \mathrm{~S}$ dibawah $50 \mathrm{ppm}$ 


\section{SIMPULAN}

Dari uraian diatas ada beberapa kesimpulan yang dapat diambil: Pemanfaatan gas bumi dari lahan gas marginal sebagai bahan bakar kendaraan bermotor menunjukkan adanya korelasi antara kebutuhan LNG dengan jarak dari kilang pencairan ke pemakai bahan bakar gas. Beberapa teknologi kilang mini LNG dapat digunakan untuk penyediaan gas ke lokasi pemakai bahan bakar gas karena dari kilang besar LNG belum tersedia sarana infrastruktur.

Dari tinjauan pustaka menunjukkan bahwa kilang mini LNG secara ekonomis lebih sesuai bagi transportasi dengan jarak lebih kurang $500 \mathrm{~km}$ dengan potensi volume tersedia kurang dari $2.5 \mathrm{MMscm} / \mathrm{d}$ atau $600-700 \mathrm{~K}$ ton/tahun. Pemanfaatan gas bumi ladang marginal di Pantura sebagai bahan bakar kendaraan bermotor, menggunakan teknologi kilang mini LNG dengan pertimbangan ketersediaan infrastruktur, jarak ekonomis dan volume ladang gas marginal. Pembangunan kilang mini LNG ada dua pilihan yaitu dekat sumber bahan baku atau dekat konsumen, hal ini untuk mempermudah sistem transportasi bahan baku maupun produk gas hingga siap dipakai sebagai bahan bakar kendaraan bermotor. Studi kasus untuk kegiatan penelitian proses pemurnian gas bumi pada kilang mini LNG menggunakan data lapangan gas marginal Cikarang -Daerah Operasi EP Pertamina Jawa Barat dengan produksi gas bumi 5,336 MMSCFD. Hasil perhitungan untuk unit pengolahan gas bumi pada kilang mini
LNG dengan kapasitas desain 2 MMCSFD diperoleh data untuk penentuan spesifikasi peralatan dan bahan konstruksi serta hal-hal yang perlu dicermati dalam pembangunan kilang mini LNG.

\section{UCAPAN TERIMAKASIH}

Pertama saya ucapkan terima kasih kepada tim kegiatan LNG mini plant, terutama Harfizal dan Akhmad Mulyana yang telah membantu dalam perhitungan proses untuk dilanjutkan pada perhitungan desain rinci peralatan utama LNG mini plant, semoga tulisan ini bisa bermanfaat bagi perkembangan kemampuan SDM bangsa Indonesia dalam penguasaan teknologi oil and gas

\section{DAFTAR PUSTAKA}

1. Kossein. A.J, et all., New Development in Gas Purification for LNG plant, LNG 10 International Conference 1992.

2. Avidan A.A., et al., LNG Links Remote Supplies and Markets, Oil and Gas Journal, June 2, 1997

3. Kikkawa Y., Nakamura M., Sugiyama S., Development of Liquefaction Process for Natural Gas, Journal of Chemical Engineering of Japan, vol. 30 No. 4 1997, pp 625- 630

4. Chiu, C., Evaluate Separation for LNG Plants, Hydrocarbon Processing, September 1978 